\title{
Biomass yield and partitioning of greenhouse grown indigenous crop Cucumis myriocarpus in response to irrigation frequency and NPK fertilizer application rate
}

\author{
R. J. Nkgapele \& M. S. Mphosi \\ Limpopo Agro-food Technology station, School of Agriculture and \\ Environmental Sciences, University of Limpopo, Republic of South Africa
}

\begin{abstract}
A study was conducted during the 2009/10 summer growing season to determine the effect of varying irrigation frequencies and NPK fertilizer application rates on biomass yield and partitioning to plant fractions of Cucumis myriocarpus. The experiment was laid out in a split-plot design arrangement and replicated five times. Three irrigation frequencies, namely, 2, 4 and 6 day interval, were the main plots and sub-plot treatments were NPK fertilizer levels combined in a ratio 3:2:1 (60-40-20 kg NPK ha-1, 120-80-40 kg NPK ha ${ }^{-1}$ and 180-120-60 kg NPK $\mathrm{ha}^{-1}$ ) and a control treatment of $0 \mathrm{Kg}$ NPK ha ${ }^{-1}$. Higher and lower total and plant fraction biomass yield were observed in the intermediate category of four day irrigation frequency, but varied among the different rates of NPK fertilizer rate. In conclusion, the results indicate that the plant can produce adequately under greenhouse conditions with moderate to limited water supply and provision of supplemental nutrients.

Keywords: irrigation frequency, biomass yield, root/shoot ratio, ethno-botanical, indigenous leafy vegetable.
\end{abstract}

\section{Introduction}

Wild watermelon, Cucumis myriocarpus, is a member of the family cucurbitaceae. All the component parts of a C. myriocarpus plant, that is, leaves, stems and roots are of consumption and ethno-botanical importance. Taken as a category, traditional vegetables are extremely important for nutrition and farm 
income throughout Africa. For example, they often supply most of the daily requirements for vitamins $\mathrm{A}, \mathrm{B}$ complex and $\mathrm{C}$ of poor rural people [1]. To produce enough biomass of high quality which can be converted to leafy vegetable, animal feed and ethno-botanicals, there is need to identify $C$. myriocarpus production and agronomic management strategies with potential for high biomass yield and specific quality traits [2].

The best economically viable management practices for growing $C$. myriocarpus must also be developed. This is necessary for farmers and rural households to benefit from the recent innovative use of indigenous leafy/ethnobotanical crops as a food and traditional medicinal resource. C. myriocarpus production is rain-fed in the Limpopo Province of South Africa and the crop is a good source of bio-nematicide [3].

Trade-offs between water productivity and nutrient requirements need to be considered carefully: maximizing water productivity in some farming systems may require NPK rates that are too costly, too risky, or environmentally unsound. This is particularly important with high fertilizer-to product price ratio, in environments prone to inorganic fertilizer leaching, or where biophysical, social, economic or infrastructure factors constrain the use of fertilizer. Likewise, trade-offs between yield and water productivity that are mediated by amount and method of water supply are common. These, and all other trade-offs need to be considered, as the aim of improving water productivity on its own is not necessarily the best pathway to sustainability as this involves specific production, environment and social targets [4].

The current study seeks to determine and demonstrate the influence of proper irrigation water management and level of NPK fertilizer application on biomass production and partitioning to plant fractions of wild watermelon, Cucumis myriocarpus, as a vital ingredients of good agronomic practice that can simply be put to use by semi-literate and illiterate smallholder producers in rural Limpopo Province of the Republic of South Africa.

\section{Materials and methods}

\subsection{Site specification}

The experiment was conducted at Horticultural Research Facility of University of Limpopo, Limpopo Province, South Africa (2353'10" S; $29^{\circ} 44^{\prime} 15^{\prime \prime}$ E) during the 2009-2010 summer growing season. Ambient day/night temperatures averaged $28 / 21^{\circ} \mathrm{C}$, with maximum temperatures controlled using thermostatically-activated fans.

\subsection{Experimental layout and treatments}

The experiment was laid out in a split-plot design arrangement and replicated five times. Three irrigation intervals, namely, 2, 4 and 6 days, were accorded as main plots. During each irrigation interval, $1000 \mathrm{ml}$ tap-water was applied per pot. Irrigation water application treatments were applied seven days after transplanting. Sub-plot treatments were accorded to varying NPK application 
rates which were $0 \mathrm{Kg}$ NPK ha ${ }^{-1}, 60-40-30 \mathrm{~kg} \mathrm{NPK} \mathrm{ha}^{-1}, 120-80-60 \mathrm{~kg} \mathrm{NPK} \mathrm{ha}{ }^{-1}$ and 180-120-90 kg NPK ha-1.

\subsection{Experimental procedures}

Seedlings were raised in seedling trays using thirty-cm-diameter plastic pots, filled with $10 \mathrm{~L}$ steam-pasteurised sand and Hygromix $(3: 1 \mathrm{v} / \mathrm{v})$, which were placed on greenhouse benches at $0.5 \mathrm{~m}$ inter-row and $0.6 \mathrm{~m}$ intra-row spacing. Uniform three-week-old Cucumis myriocarpus seedlings were transplanted to the pots one day after irrigating the growing medium to field capacity. The first experiment was harvested at 40 days after transplanting (DAT) and the second at 60 DAT. NPK fertilizer $(2: 3: 2)$ was given in split doses. First dose was applied at transplanting of seedlings into $30 \mathrm{~cm}$ plastic pots, while the remaining dose was applied 20 days after the first dose.

\subsection{Cultural practices and data collection}

Agronomic cultural practices of pest control and weed removal were carried out throughout the growing season as recommended. Plants were harvested 40 days after transplanting (40 DAT) to determine vegetative yield responsiveness. The data was recorded using a standard balance scale for biomass yield, leaf, stem and root, Root/Shoot ratios and productivity score of fresh samples. The samples were later subjected to oven dry at $65^{\circ} \mathrm{C}$ for 24 hours to determine the dry biomass of the same parameters.

\subsection{Data analysis}

The data of all the above mentioned were individually subjected to the analysis of variance techniques using Statistix 8.1 software (Statistix, Analytical Software, Statistix; Tallahassee, FL, USA, 1985-2003). Mean comparisons were done using least significance difference (LSD) at 0.05 level of probability $[5,6]$. When treatments were significant sum of squares were partitioned to determine the percentage contribution of source of variation to the total treatment variation [7].

\section{Results}

\subsection{Total biomass yield}

The results showed that total fresh and dry biomass yields were influenced $(\mathrm{P}<$ 0.05 ) by the interaction between irrigation frequency and NPK fertilizer application rate. Irrigation frequency, NPK fertilizer application rate and their interaction contributed $14.3,24.6$ and $23.6 \%$ to the total treatment variations of fresh biomass, correspondingly (Table 1). The highest fresh biomass yield was $285 \%$ higher than lowest biomass yields. Dry biomass yield was only influenced by NPK fertilizer application rate which contributed $49.7 \%$ total treatment variations (Table 2), with the highest yield 147\% higher than the lowest biomass yield (Fig. 1). 
Table 1: $\quad$ Analysis of variance for fresh shoot and total biomass yield to plant fractions of Cucumis myriocarpus as affected by irrigation interval and NPK application rate during the 2009/10 summer growing season.

\begin{tabular}{|l|l|l|l|l|l|}
\hline Source of variation & \multirow{2}{*}{ df } & \multicolumn{2}{|l|}{ Shoot $\left(\mathbf{g ~ m ~ m}^{\mathbf{- 2}}\right)$} & \multicolumn{2}{l|}{ Biomass yield $\left(\mathbf{k g ~ h a}^{\mathbf{- 1}}\right)$} \\
\cline { 3 - 6 } & & $\mathbf{S S}$ & $\mathbf{\%}$ & SS & \% \\
\hline Replicate (A) & 2 & 237881 & 8.92 & 46990000 & 12.3 \\
\hline Irrigation (B) & 2 & 315831 & 11.8 & 54530000 & $14.3^{* *}$ \\
\hline Error $\left(\mathrm{A}^{*} \mathrm{~B}\right)$ & 4 & 71510 & 2.68 & 12830000 & 3.35 \\
\hline NPK rate $(\mathrm{C})$ & 3 & 695669 & $26.1^{* *}$ & 94200000 & $24.6^{* * *}$ \\
\hline B*C & 6 & 765221 & $28.7^{* *}$ & 90260000 & $23.6^{* *}$ \\
\hline Error $\left(\mathrm{A}^{*} \mathrm{~B}^{*} \mathrm{C}\right)$ & 18 & 579881 & 21.8 & 83770000 & 21.9 \\
\hline Total & 35 & 2665994 & 100 & 382580000 & 100 \\
\hline
\end{tabular}

*** Significant $(\mathrm{P}<0.01)$, ** Significant $(\mathrm{P}<0.05), \mathrm{Df}=$ degree of freedom, $\mathrm{SS}=$ sum of squares, ns $=$ non-significant.

Table 2: $\quad$ Analysis of variance for dry shoot and total biomass yield to plant fractions of Cucumis myriocarpus as affected by irrigation interval and NPK application rate during the 2009/10 summer growing season.

\begin{tabular}{|c|c|c|c|c|c|}
\hline \multirow[t]{2}{*}{ Source of variation } & \multirow[t]{2}{*}{ df } & \multicolumn{2}{|c|}{ Shoot $\left(\mathrm{g} \mathrm{m}^{-2}\right)$} & \multicolumn{2}{|c|}{ Biomass yield $\left(\mathrm{kg} \mathrm{ha}^{-1}\right)$} \\
\hline & & SS & $\%$ & SS & $\%$ \\
\hline Replicate (A) & 2 & 9531 & 6.36 & 872420 & 4.25 \\
\hline Irrigation (B) & 2 & 9632 & $6.43 \mathrm{~ns}$ & 847660 & $4.13 \mathrm{~ns}$ \\
\hline Error $(\mathrm{A} * \mathrm{~B})$ & 4 & 7137 & 4.76 & 1112169 & 5.42 \\
\hline NPK rate $(\mathrm{C})$ & 3 & 71335 & $47.6 * * *$ & 10200007 & $49.7 * * *$ \\
\hline $\mathrm{B} * \mathrm{C}$ & 6 & 10341 & $6.90 \mathrm{~ns}$ & 1310210 & $6.38 \mathrm{~ns}$ \\
\hline Error $(A * B * C)$ & 18 & 41831 & 27.9 & 6188699 & 30.1 \\
\hline Total & 35 & 149806 & 100 & 20531165 & 100 \\
\hline
\end{tabular}

\subsection{Shoot biomass yield}

Significant $(\mathrm{P}<0.05)$ differences were demonstrated in fresh shoot biomass accumulation in response to irrigation frequency and NPK fertilizer application rate, while dry biomass responded only to NPK application rate. NPK application rate and the interaction between irrigation application frequency and NPK application accounted for 26.1 and $28.7 \%$ of the total variation for fresh shoot biomass yield, while NPK application rate contributed $47.6 \%$ for dry shoot yield (Tables 1 and 2). The highest fresh and dry shoot biomass accumulation were 355 and $166 \%$ higher than lowest yielding treatment (Fig. 2). 


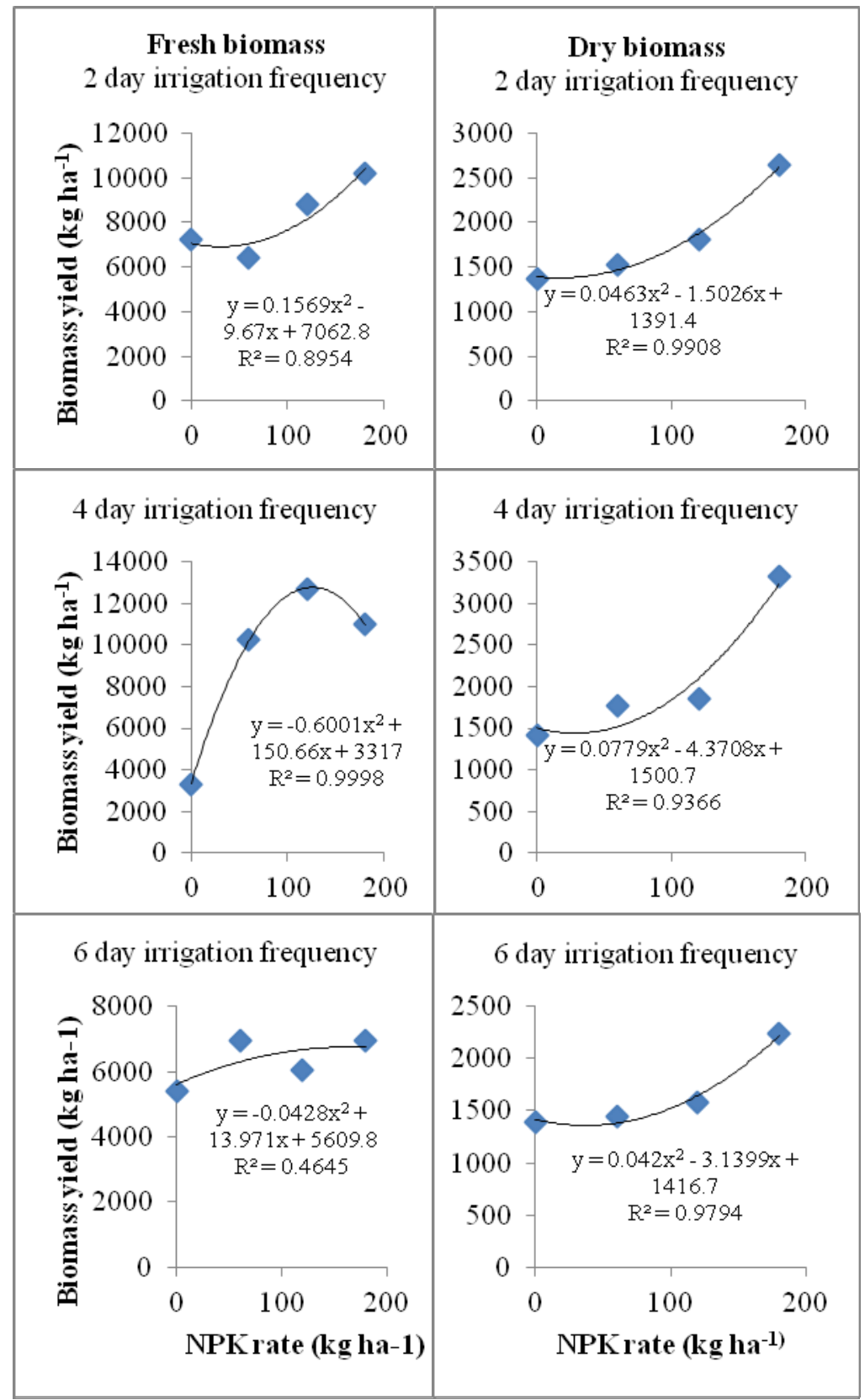

Figure 1: $\quad$ Fresh and dry biomass yield in response to irrigation frequency and NPK application rate at 40 DAT during the 2009/10 summer growing season. 


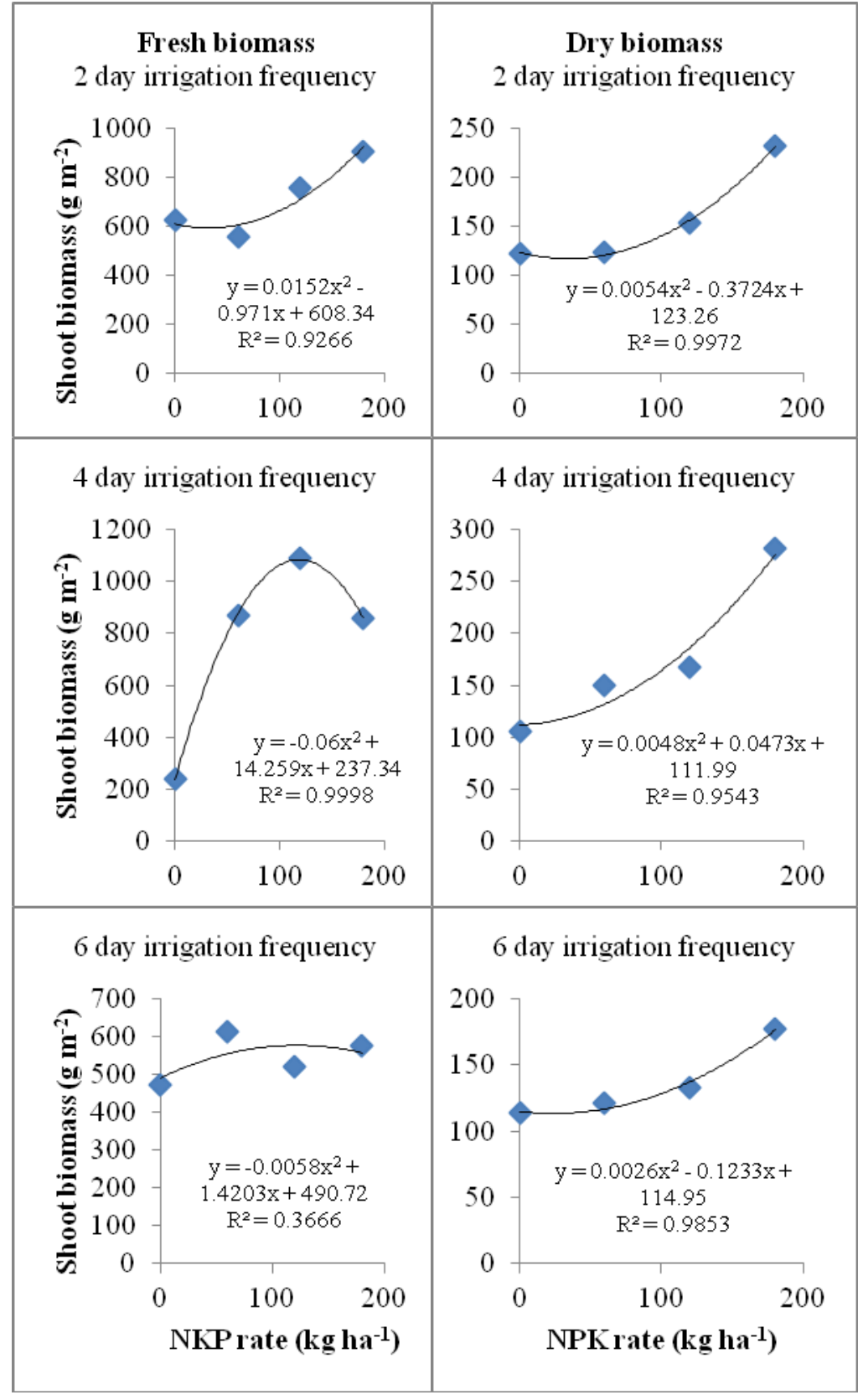

Figure 2: $\quad$ Root biomass yield as influenced by irrigation frequency and level of NPK fertilizer application during the 2009/10 cropping season. 


\subsection{Biomass partitioning to roots}

Significant differences $(\mathrm{P}<0.05)$ were observed on fresh and dry root biomass accumulation. Fresh and dry root biomass responded positively to irrigation frequency while leaves responded to NPK fertilizer application rate with the treatment contributing 12.6 and $29.1 \%$ to total treatment variation (Tables 3 and 4). The highest fresh and dry root biomass were respectively 258 and $241 \%$ higher than the least biomass producing treatment (Fig. 3).

Table 3: Analysis of variance for fresh biomass partitioning to plant fractions of Cucumis myriocarpus as affected by irrigation interval and NPK application rate during the 2009/10 summer growing season.

\begin{tabular}{|c|c|c|c|c|c|c|c|}
\hline \multirow{2}{*}{$\begin{array}{l}\text { Source of } \\
\text { variation }\end{array}$} & \multirow[t]{2}{*}{ Df } & \multicolumn{2}{|l|}{ Roots } & \multicolumn{2}{|l|}{ stems } & \multicolumn{2}{|l|}{ leaves } \\
\hline & & SS & $\%$ & SS & $\%$ & SS & $\%$ \\
\hline Replicate (A) & 2 & 40274 & 20.8 & 137452 & 15.6 & 17156 & 2.10 \\
\hline Irrigation (B) & 2 & 41408 & $21.4 \mathrm{~ns}$ & 118030 & $13.4 \mathrm{~ns}$ & 49227 & $5.92 \mathrm{~ns}$ \\
\hline Error $(\mathrm{A} * \mathrm{~B})$ & 4 & 24140 & 12.5 & 61529 & 7.00 & 67375 & 8.11 \\
\hline NPK rate $(\mathrm{C})$ & 3 & 24377 & $12.6^{* *}$ & 213517 & $24.3 * * *$ & 172573 & $20.8^{* *}$ \\
\hline $\mathrm{B} * \mathrm{C}$ & 6 & 17552 & $9.10 \mathrm{~ns}$ & 152380 & $17.3 \mathrm{~ns}$ & 288685 & $34.7 * *$ \\
\hline Error $(A * B * C)$ & 18 & 45416 & 23.5 & 195697 & 22.3 & 236164 & 28.4 \\
\hline Total & 35 & 193169 & 100 & 878605 & 100 & 831180 & 100 \\
\hline
\end{tabular}

*** Significant $(\mathrm{P}<0.01), * *$ Significant $(\mathrm{P}<0.05), \mathrm{Df}=$ degree of freedom, $\mathrm{SS}=$ sum of squares, ns=non-significant.

Table 4: $\quad$ Analysis of variance for dry biomass partitioning to plant fractions of Cucumis myriocarpus as affected by irrigation interval and NPK application rate during the 2009/10 summer growing season.

\begin{tabular}{|l|l|l|l|l|l|l|l|}
\hline $\begin{array}{l}\text { Source } \\
\text { variation }\end{array}$ & Df & Roots & \multicolumn{2}{l|}{ stems } & leaves \\
\cline { 3 - 8 } & & SS & $\%$ & SS & $\%$ & SS & $\%$ \\
\hline Replicate (A) & 2 & 159.7 & 1.61 & 1652 & 4.67 & 3304 & 6.09 \\
\hline Irrigation (B) & 2 & 83.59 & $0.85 \mathrm{~ns}$ & 3389 & $9.58 \mathrm{~ns}$ & 2300 & $4.24 \mathrm{~ns}$ \\
\hline Error $\left(\mathrm{A}^{*} \mathrm{~B}\right)$ & 4 & 1512 & 15.3 & 2023 & 5.72 & 4209 & 7.76 \\
\hline NPK rate $(\mathrm{C})$ & 3 & 2876 & $29.1 * *$ & 17416 & $49.2^{* * *}$ & 21386 & $39.4^{* * *}$ \\
\hline $\mathrm{B} * \mathrm{C}$ & 6 & 927.2 & $9.37 \mathrm{~ns}$ & 4284 & $12.1 \mathrm{~ns}$ & 2852 & $5.26 \mathrm{~ns}$ \\
\hline Error $\left(\mathrm{A}^{*} \mathrm{~B}^{*} \mathrm{C}\right)$ & 18 & 4333 & 43.8 & 6618 & 18.7 & 20191 & 37.2 \\
\hline Total & 35 & 9892 & 100 & 35381 & 100 & 54241 & 100 \\
\hline
\end{tabular}

$* * *$ Significant $(\mathrm{P}<0.01), * *$ Significant $(\mathrm{P}<0.05), \mathrm{Df}=$ degree of freedom, $\mathrm{SS}=$ sum of squares, ns=non-significant.

\subsection{Biomass partitioning to stems}

Highly significant variances $(\mathrm{P}<0.01)$ were observed on fresh and dry stem biomass accumulation. Fresh and dry stems responded positively to NPK fertilizer application rate, with 24.3 and $49.2 \%$ contribution to treatment variation, respectively (Tables 3 and 4). Higher fresh and dry stem biomass yield were 328 and 195\% higher than lowest yielding treatment mixtures (Fig. 4). 


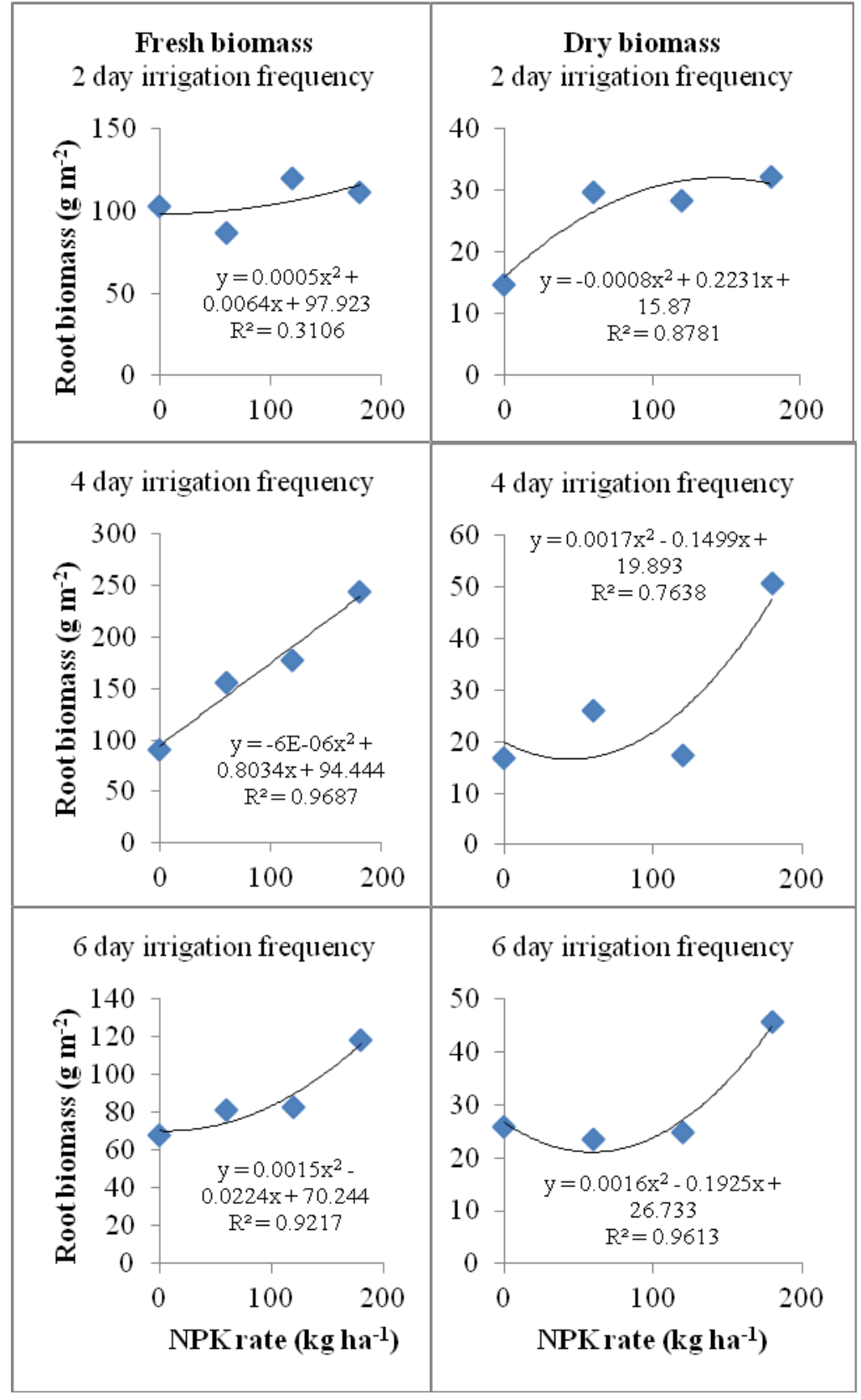

Figure 3: $\quad$ Stem biomass yield as influenced by irrigation frequency and level of NPK application rate during the 2009/10 cropping season. 


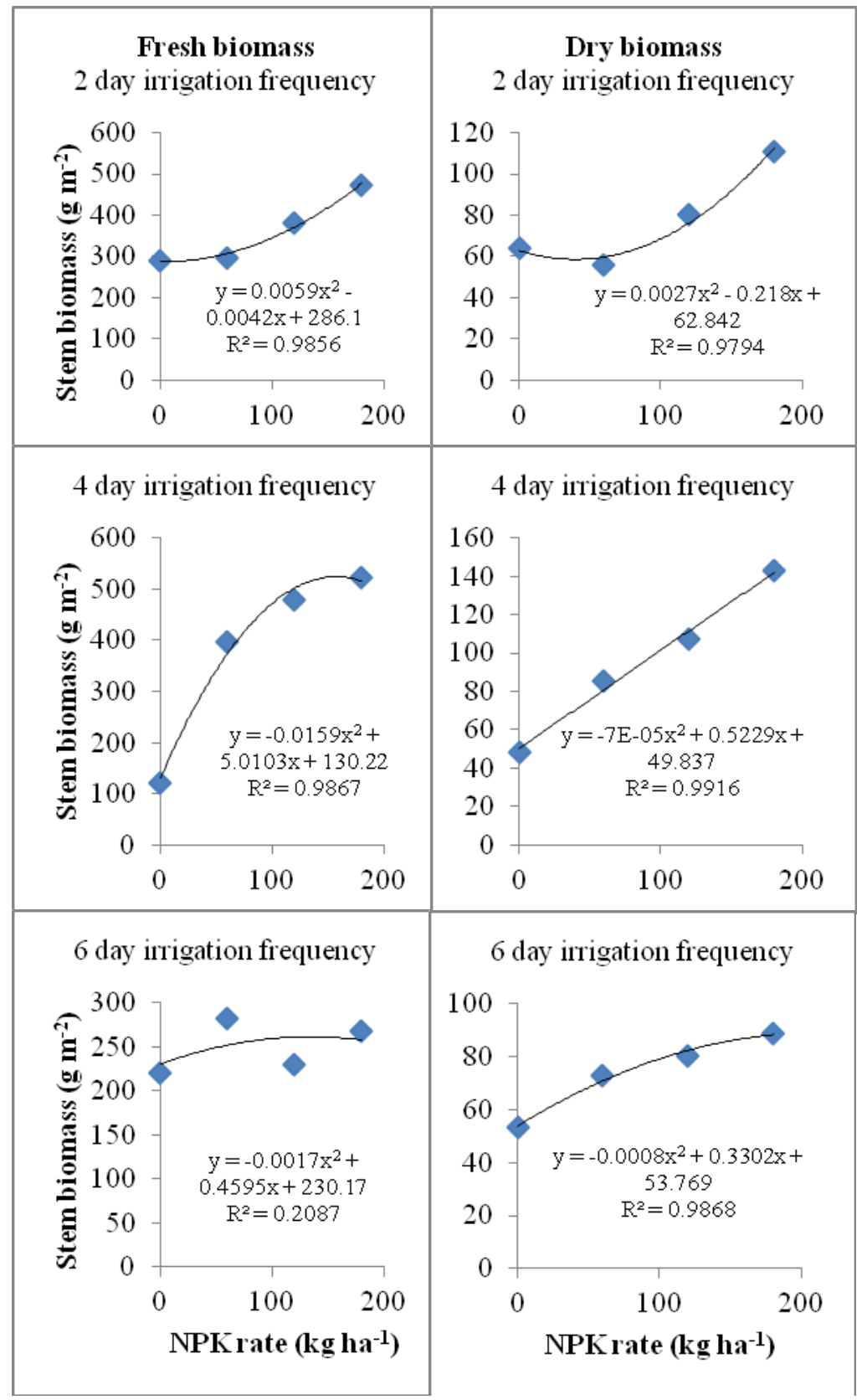

Figure 4: Leaf biomass yield as influenced by irrigation frequency and level of NPK fertilizer application during the 2009/10 cropping season. 


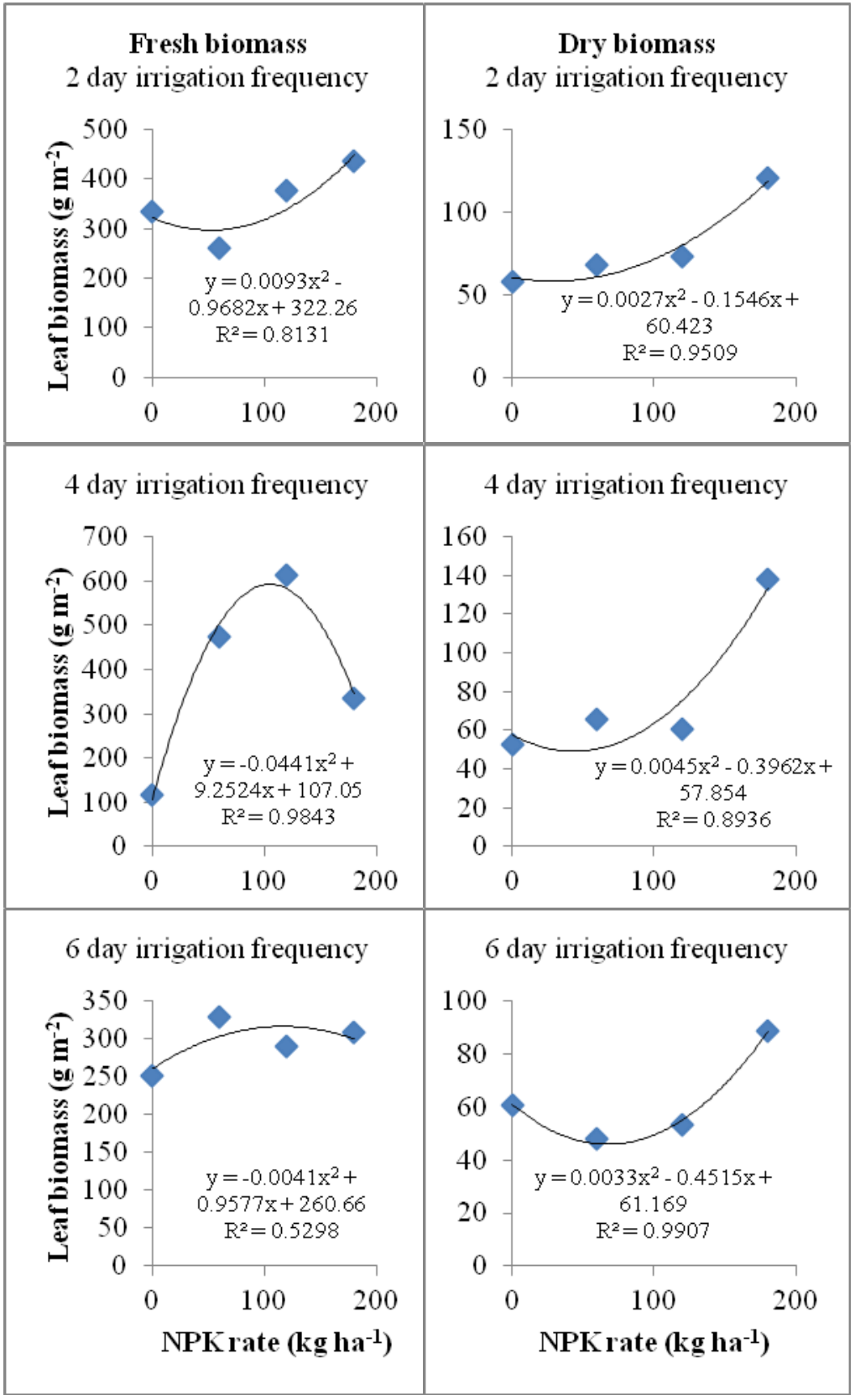

Figure 5: Leaf biomass yield as influenced by irrigation frequency and level of NPK fertilizer application during the 2009/10 cropping season. 


\subsection{Biomass partitioning to leaf fractions}

The highest fresh and dry leaf biomass which showed significant responses $(\mathrm{P}<$ $0.05)$ were 423 and $187 \%$ higher than the least yielding treatment, correspondingly (Fig. 5). Fresh leaf yield responded to NPK application rate and the interaction between irrigation frequency which were responsible for correspondingly 20.8 and $34.7 \%$ to variation, while dry leaf yield responded only to NPK application rate with contribution to treatment variation of $39.4 \%$ (Tables 3 and 4).

\section{Discussion}

Adequate biomass supply of indigenous crops such as $C$. myriocarpus are required for both consumption as a leafy vegetable and use as ethno-botanicals in many rural areas of developing regions[8,9]. The results of the study show that by applying intermediate irrigation frequency and NPK rate substantially high amounts of fresh and dry biomass yields of $C$. myriocarpus that are required by the rural populace can be achieved. Consequently, with the advent of escalating water shortages [10] and lack of inorganic fertilizer-inputs supplies [11] in rural communities it can be deduced from the above findings that smallholder farmers can produce $C$. myriocarpus with infrequent irrigation episodes and minimal nutrient inputs applications.

An additional benefit to diets of indigenous leafy vegetables consumers is that it is reported by several workers that they can contribute with significant amounts of vitamins and minerals, and are especially excellent sources of protein, carotene, iron and ascorbic acid [12, 13]; an attribute that can greatly assist in the fight against the hidden hunger prevalent in many rural areas.

In our study partitioning of biomass to roots, stems and leaves, was found to be significantly influenced by irrigation frequency and NPK rate at intermediate levels of application. These results agree with findings by several workers on other vegetable crops, [14] in watermelon, [15] in cucumber, [16] in bell pepper, [15] in Brassica rapa L. subsp. chinensis and Solanum retroflexum Dun

\section{Conclusions}

In conclusion, the results indicate that the plant can produce adequately under greenhouse conditions with moderate to limited water supply and provision of supplemental nutrients. Additionally, the study showed significant influences that varying irrigation water application frequencies and different levels of NPK fertilizer application has on biomass yield and partitioning. The highest Cucumis myriocarpus plant fraction harvest of fresh and dry roots $\left(243.2\right.$ and $\left.50.62 \mathrm{~g} \mathrm{~m}^{-2}\right)$, stem (523.5 and $143.2 \mathrm{~g} \mathrm{~m}^{-2}$ ); leaf (613.6 and $\left.138.3 \mathrm{~g} \mathrm{~m}^{-2}\right)$ and shoot (1091 and $281.5 \mathrm{~g} \mathrm{~m}^{-2}$ ) were obtained in the four day irrigation interval. A crop biomass harvest under these conditions produced fresh and dry biomass yields of correspondingly 12691 and $3321 \mathrm{~kg} \mathrm{ha}^{-1}$. 


\section{References}

[1] Ndlovu, J., and Afolayan, A.J. Nutritional analysis of the South African wild vegetable Corchorus olitorius L. Asian Journal of Plant Science, pp. 1-4, 2008.

[2] Nkgapele, R.J., Mphosi M.S., and Mashela, P.W. Effect of irrigation amount and frequency on phenology, vine length and biomass partitioning of wild cucumber (Cucumis myriocarpus) and wild watermelon (Cucumis africanus). Water Resource Management VI, WIT press, Wessex Institute of Technology, UK, pp. 557-564, 2011.

[3] Mafeo, T.P. and Mashela, P.W. Responses of germination in tomato, watermelon and butternut squash to Cucumis bionematicide. Journal of Agriculture and Environment Science 6, pp. 215-219, 2009.

[4] FAO. Fertilizer use by crops in South Africa. FAO, Rome, pp. 16-21, 2005.

[5] Gomez KA, Gomez AA (1984). Statistical procedures for agricultural research $2^{\text {nd }}$ ed. John Wiley \& Sons, New York., pp. 146-184, 1984.

[6] Kuehl R.O. Design of experiments: statistical principles of research design and analysis $2^{\text {nd }}$ ed. Duxbury press, New York., pp. 173-184, 2000.

[7] Little, T.M. and Hills, F.J. Statistical methods in agricultural research, University of California, California, USA, pp. 350, 1981.

[8] Jansen van Rensburg, W.S., van Averbeke, W., Slabbert, R., Faber, M., van Jaarsveld, P., van Heerden, I., Wenhold, F., and Oelofse, A. African leafy vegetables in South Africa. Water SA, 33 (3), 317-326, 2007.

[9] Auwalu, B.M., and Babatunde, F.E. Analysis of growth, yield and fertilization of vegetable Sesame (Sesamum radiatum Schum). Journal of Plant Science, 2(1), pp. 108-112, 2007.

[10] Atta, S., Seyni, H.H., Bakasso, Y., Sarr, B., Lona, I. and Saadou, M. Yield character variability in Roselle (Hibiscus sabdariffa L.). African Journal of Agricultural Research, 6(6), pp. 1371-1377, 2011.

[11] Van Soest, P.J., Use of detergents in the analysis of fibrous feeds, II: A rapid method for the determination of fiber and lignin. Journal of Association of Office of Agricultural Chemistry, 46, 829-835, 1963.

[12] Luyen, L.T., and Preston, T. R. Effect of level of urea fertilizer on biomass production of water spinach (Ipomoea aquatica) grown in soil and in water. Livestock Research for Rural Development, 16, 2004.

[13] Erdem, Y., Yüksel, A.N., and Orta, A.H. The effects of deficit irrigation on watermelon yield, water use and quality characteristics. Pakistan Journal of Biological Science, 4(7), 785-789, 2001.

[14] Waseem, K., Kamran, Q.M., and Jalani, M.S. Effect of different nitrogen levels on growth and yield of cucumber (Cucumis sativus L.). Journal of Agricultural Research, 46(3), pp. 259-266, 2008.

[15] Khan MH, Chattha TH, Saleem N (200). Influence of different irrigation intervals on growth and yield of bell pepper (Capsicum Annuum Grossum Group). Res. J. Agri. Bio. Sci., 1(2): 125-128, 2005. 
[16] Van Averbeke, W., and Juma, K.A. The cultivation of Solanum retroflexum Dun. in Vhembe, Limpopo Province, South Africa. Proc. Int. Symp. on the Nutritional Value and Water Use of Indigenous Crops for Improved Livelihoods. 19-20 September 2006, University of Pretoria, Pretoria. [CD ROM]. The Centre for Nutrition, University of Pretoria, Pretoria. 